\title{
PCR identification of Trichophyton mentagrophytes var. interdigitale and $T$. mentagrophytes var. mentagrophytes dermatophytes with a random primer
}

\author{
D. LIU, S. COLOE, R. BAIRD and J. PEDERSEN \\ Melbourne Pathology, 32 Smith Street, Collingwood, Victoria 3066, Australia
}

\begin{abstract}
Dermatophytes are a group of keratinophilic fungi falling within the genera of Epidermophyton, Microsporum and Trichophyton. The genus Trichophyton is particularly important and complex; it comprises at least 15 recognised species. In addition, there are several different variants in the species $T$. mentagrophytes, which occur both in man and animals. The current methods of determining $T$. mentagrophytes varieties may require several different culture media and time-consuming procedures, as well as specialist skills. This study used a random primer, 5'-GAGCCCGACT-3', in the arbitrarily primed polymerase chain reaction (AP-PCR) and showed that the two common $T$. mentagrophytes varieties (var. interdigitale and var. mentagrophytes) can be clearly identified on the basis of their characteristic DNA band patterns. The relative reproducibility, ease of use and precision of this method make the AP-PCR a valuable tool in the laboratory diagnosis of human dermatophytosis.
\end{abstract}

\section{Introduction}

Tinea (or ringworm) is a common disease of man and animals resulting from the infection of skin, hair and nails by keratinophilic fungi - dermatophytes. Taxonomically dermatophytes are divided into three genera: Epidermophyton, Microsporum and Trichophyton. While Epidermophyton is represented by a single species (E. floccosum), Microsporum and Trichophyton contain multiple species, many of which are pathogenic to man [1].

The genus Trichophyton is particularly important, and represents the most frequently isolated of all dermatophytes from human patients. According to recent surveys, T. rubrum makes up c. 55\% and T. tonsurans $31 \%$ of the clinical dermatophyte isolations in the USA [2-3]. Similarly, T. rubrum accounts for $65 \%$ and $T$. mentagrophytes $32 \%$ of the clinical isolations in Victoria, Australia (unpublished data). The genus Trichophyton is also extremely complex. Apart from the existence of at least 15 recognised species in the genus [1], there are several different variants within the species of $T$. mentagrophytes, occurring both in man and animals [4]. While T. mentagrophytes var.

Received 18 Feb. 1997; revised version accepted 1 June 1997.

Corresponding author: Dr D. Liu. interdigitale is anthropophilic and frequently found in man, T. mentagrophytes var. mentagrophytes is zoophilic and isolated mainly from animals. Furthermore, T. mentagrophytes var. quinckeanum is seen in rodents, and $T$. mentagrophytes var. erinacei is associated with hedgehogs [4]. Interestingly, some authors refer to the different varieties of $T$. mentagrophytes as separate species, e.g., $T$. interdigitale rather than T. mentagrophytes var. interdigitale. Although some zoophilic varieties of $T$. mentagrophytes produce only minor or subclinical infections in animals, they can initiate a severe inflammatory response in man [4]. Therefore, from an epidemiological point of view, it is important to determine the variety of $T$. mentagrophytes and its origin in order to prevent spread of infection.

At present, the laboratory identification of Trichophyton species and varieties is based on microscopic examination and in-vitro culture. The current methods of determining $T$. mentagrophytes varieties may involve several different culture media such as Littman Oxgall agar, Lactritmel agar, Sabouraud's dextrose agar with $\mathrm{NaCl} 5 \%$, peptone agar $1 \%$, hydrolysis of urea, vitamin-free agar (Trichophyton no. 1 agar) and in-vitro hair perforation test. These tests are costly and time-consuming and also demand specialist skills. Therefore, it is no surprise that some results may take weeks to produce. 
With the development of polymerase chain reaction (PCR) technology, in particular the application of the arbitrarily primed PCR (AP-PCR) or random amplified polymorphic DNA (RAPD) technique [5-7], the potential to accelerate and improve the laboratory diagnosis of dermatophytes has been greatly enhanced. The PCR technology enables rapid detection and determination of various dermatophytes from minute amounts of starting materials, and the AP-PCR has the additional advantage of obviating the need to know the detailed sequences of the gene regions concerned as well as the necessity to further manipulate after amplification. A recent study demonstrated that the use of a random primer ( $5^{\prime}$-ACCCGACCTG-3') in the AP-PCR can rapidly differentiate several common Trichophyton dermatophytes including T. rubrum, $T$. mentagrophytes and T. tonsurans [8]. However, $T$. mentagrophytes var. interdigitale and var. mentagrophytes formed identical DNA band patterns, and could not be distinguished with the random decamer $5^{\prime}$ ACCCGACCTG-3' in the AP-PCR [8]. This prompted the search for additional random primers that could be used in the AP-PCR for improved determination of $T$. mentagrophytes varieties, especially between the two common varieties, $T$. mentagrophytes var. interdigitale and var. mentagrophytes. This study provides evidence that $T$. mentagrophytes var. interdigitale and var. mentagrophytes are distinguishable on the basis of their characteristic DNA bands amplified through the AP-PCR with a different random primer, 5'GAGCCCGACT-3'. Future examination of the nucleotide base sequences of the specific bands observed will provide further insights into the genetic structures and possible functions of the gene regions involved. This in turn will lead to improved understanding of the genetic relationship among different $T$. mentagrophytes varieties, as well as enhanced diagnosis of human dermatophytosis.

\section{Materials and methods}

\section{Dermatophytes}

Dermatophytes were routinely isolated in this laboratory from infected skin, nails and hair of human patients. Initially, a small proportion of the samples was suspended in a drop of examination buffer -$0.5 \mathrm{ml}$ of Blankophor BA 267 (Bayer) $0.1 \% \mathrm{w} / \mathrm{v}$, $0.5 \mathrm{ml}$ of $\mathrm{KOH} 10 \%$ and glycerol $50 \mu \mathrm{l}$ - for detection by fluorescent microscopy. The samples were then inoculated on to Dermasel Agar (Oxoid) and Sabouraud Dextrose Agar (Oxoid) for incubation at $26^{\circ} \mathrm{C}$ for up to 4 weeks. The resultant dermatophyte isolates were identified by microscopic and culture techniques. Lactritmel agar, Chistensens urea, Sabouraud dextrose agar with $\mathrm{NaCl} 5 \%$, peptone agar $1 \%$ and Littman Oxgall agar were used for identification of $T$. mentagrophytes var. mentagrophytes and Lactritmel agar, Christensens urea, and occasionally Littman Oxgall agar for $T$. mentagrophytes var. interdigitale.
In the present study, 64 dermatophyte isolates were examined by the AP-PCR (Table 1). These included Trichophyton mentagrophytes var. interdigitale (20 isolates), T. mentagrophytes var. mentagrophytes (four), T. mentagrophytes var. quinckeanum (seven), T. mentagrophytes var. erinacei (one), $T$. rubrum (10), $T$. violaceum (three), T. ajelloi (one), T. equinum var. autotrophicum (one), T. schoenleinii (one), T. terrestre (one), T. tonsurans (six), Microsporum canis (three), $M$. persicolor (one), M. cookei (one) and Epidermophyton floccosum (four) (Table 1). Except for T. mentagrophytes var. quinckeanum, T. ajelloi, T. equinum var. autotrophicum, T. schoenleinii and T. terrestre isolates, which were obtained from reference collections in Australia and New Zealand, all dermatophytes under investigation originated from clinical samples in this laboratory. It is of interest to note that while $T$. mentagrophytes var. interdigitale was generally isolated from feet (including interdigital skins and toe nails), three of the four $T$. mentagrophytes var. mentagrophytes isolates were from the skin scrapings of the forearms of animal handlers who had dealt with an infected kangaroo, and the other from the chin of a child who had been playing with an infected pet.

\section{Purification of fungal genomic DNA}

Genomic DNA from dermatophyte isolates was purified as described previously [8]. Briefly, a dermatophyte isolate grown on a primary culture slope was collected with a sterile spatula into a $15-\mathrm{ml}$ tube with $4 \mathrm{ml}$ of SET buffer ( $75 \mathrm{mM} \mathrm{NaCl}, 25 \mathrm{~mm}$ EDTA, $20 \mathrm{mM}$ Tris$\mathrm{HCl}, \mathrm{pH} 8$ ). The mycelia were disrupted by mechanical shearing several times through an 18-gauge needle. Following the addition of $1 \mathrm{ml}$ of freshly made lysozyme solution (Boehringer) $2.5 \mathrm{mg} / \mathrm{ml}$, the tubes were incubated at room temperature for $1 \mathrm{~h}, 25 \mu \mathrm{l}$ of RNAase (free of DNAase) $10 \mathrm{mg} / \mathrm{ml}$ were added, and the tubes were incubated at $37^{\circ} \mathrm{C}$ for $30 \mathrm{~min}$. Next, $500 \mu \mathrm{l}$ of $\mathrm{SDS} 10 \%$ and $50 \mu \mathrm{l}$ of proteinase $\mathrm{K}$ $10 \mathrm{mg} / \mathrm{ml}$ were added and the tubes were incubated at $50^{\circ} \mathrm{C}$ for $1 \mathrm{~h}$. Then $2 \mathrm{ml}$ of $6 \mathrm{M} \mathrm{NaCl}$ and $7.5 \mathrm{ml}$ of chloroform were added, mixed gently in a rotating shaker for $10 \mathrm{~min}$ and centrifuged at $3500 \mathrm{rpm}$ for $20 \mathrm{~min}$. The supernatent was transferred to a new 15 $\mathrm{ml}$ tube, and the DNA was precipitated with isopropanol $7.5 \mathrm{ml}$ by gentle inversion and subsequent centrifugation at $3500 \mathrm{rpm}$ for $20 \mathrm{~min}$ at $4^{\circ} \mathrm{C}$. After washing with ethanol $70 \%$, the DNA was vacuumdried and dissolved in $1 \mathrm{ml}$ of $1 \times \mathrm{TE}(10 \mathrm{mM}$ Tris$\mathrm{HCl}, \mathrm{pH} 8.0$, and $1 \mathrm{mM}$ EDTA, $\mathrm{pH} \mathrm{8.0)}$. The DNA concentration was determined by absorption at UV $260 \mathrm{~nm}$ in a spectrophotometer, and a sample of the purified DNA was diluted to $c$. $10 \mathrm{ng} / \mu \mathrm{l}$ in sterile water which was stored at $-20^{\circ} \mathrm{C}$ until used.

\section{Arbitrarily primed PCR (AP-PCR)}

The arbitrarily primed PCR was performed in a reaction mixture volume of $30 \mu \mathrm{l}$. The reaction mixture 
was made up of c. $10 \mathrm{ng}$ of genomic DNA, $50 \mathrm{mM}$ $\mathrm{KCl}, 10 \mathrm{mM}$ TRis- $\mathrm{HCl}$ ( $\mathrm{pH} 9.0$ ), $10 \mathrm{mM} \mathrm{NaCl}, 0.5 \mathrm{mM}$ DTT, $2.5 \mathrm{mM} \mathrm{MgCl}_{2}$, Triton X-100 $0.1 \%, 200 \mu \mathrm{M}$ of each of dNTPs (dATP, dCTP, dGTP and dTTP), $0.7 \mathrm{U}$ of Taq DNA polymerase (Life Technologies) and $15 \mathrm{pmol}$ of one of the 60 random decamers (Operon Technologies, USA). The reaction mixture was incubated in a GeneAmp ${ }^{\mathrm{TM}}$ PCR System 9600 (Perkin Elmer, Roche, USA) following the following protocol: three cycles of $94^{\circ} \mathrm{C}$ for $60 \mathrm{~s}, 36^{\circ} \mathrm{C}$ for $45 \mathrm{~s}, 72^{\circ} \mathrm{C}$ for $90 \mathrm{~s}$ and 32 cycles of $94^{\circ} \mathrm{C}$ for $30 \mathrm{~s}, 36^{\circ} \mathrm{C}$ for $45 \mathrm{~s}$, $72^{\circ} \mathrm{C}$ for $90 \mathrm{~s}$. A tube with no template DNA was included as a negative control. Upon completion, $5 \mu \mathrm{l}$ of $10 \times$ DNA sample buffer containing bromophenol and glycerol were added to each tube, from which $c$. $10 \mu \mathrm{l}$ was electrophoresed (at $5 \mathrm{~V} / \mathrm{cm}$ ) in an agarose $1.5 \% \mathrm{gel}$ in $1 \times \mathrm{TAE}$ buffer in the presence of ethidium bromide, and subsequently detected under UV light.

\section{Results}

Most $T$. mentagrophytes var. interdigitale and var. mentagrophytes isolates could be distinguished on the basis of their gross colonial and microscopic morphology, as the former tended to have powdery to downy colonies and the latter powdery to granular colonies. Microscopically, both varieties possessed septate hyphae with single-celled hyaline microconidia, of which T. mentagrophytes var. interdigitale were subspherical to pyriform and var. mentagrophytes were spherical to subspherical. Nevertheless, T. mentagrophytes var. mentagrophytes isolates generally had more smooth, thin-walled, clavate multiseptate macroconidia than var. interdigitale. For some isolates, the cultural characteristics were inconsistent, and further testing was required to confirm their identity. Although both varieties hydrolysed urea, T. mentagrophytes var. mentagrophytes isolates often produced a yellowish diffusible pigment on Littman Oxgall agar, which was absent from cultures of var. interdigitale.

The results of the arbitrarily primed PCR appeared to be more discriminatory. Of the 60 random decamers examined in the AP-PCR, one primer (5'-GAGCCCGACT-3') produced distinct band patterns from genomic DNA of different Trichophyton species and varieties (Fig. 1 and Table 1). It was particularly noticeable that while $T$. mentagrophytes var. interdigitale isolates generated DNA bands of 3.5, 2.8 and $1.3 \mathrm{~kb}$ (Fig. 1b-g), T. mentagrophytes var. mentagrophytes isolates had bands of 3.5 and $2.8 \mathrm{~kb}$ only (Fig. $1 \mathrm{~h}-\mathrm{k}$ ) in AP-PCR with this primer. Furthermore, the

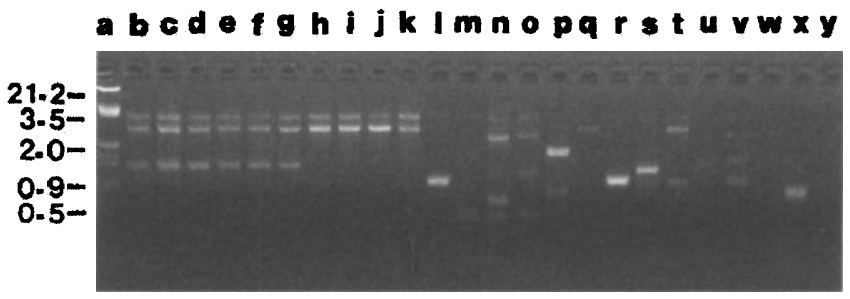

Fig. 1. Agarose gel electrophoresis of dermatophyte DNA products generated through the arbitrarily primed PCR with the random primer 5'-GAGCCCGACT-3'. Lane a, DNA mol.wt marker ( $\lambda$ HindIII $+E c o$ RI) in kb; b-g, DNA products amplified from $T$. mentagrophytes var. interdigitale isolates; $\mathbf{h}-\mathbf{k}, T$. mentagrophytes var. mentagrophytes isolates; $\mathbf{l}, T$. mentagrophytes var. quinckeanum; m, T. mentagrophytes var. erinacei; $\mathbf{n}, T$. rubrum; $\mathbf{0}, T$. violaceum; p, T. ajelloi; $\mathbf{q}, T$. equinum var. autotrophicum; $\mathbf{r}, T$. schoenleinii; $\mathbf{s}$, T. terrestre; t, T. tonsurans; $\mathbf{u}, M$. canis; v, M. periscolor; w, M. cookei; $\mathbf{x}$, E. floccosum; y, negative control with no template DNA.

Table 1. Summary of dermatophyte species and varieties examined in arbitrarily primed PCR with the random primer $5^{\prime}$-GAGCCCGACT-3'

\begin{tabular}{llr}
\hline Dermatophyte species and varieties & PCR bands (kb) & Number of isolates tested \\
\hline T. mentagrophytes var. interdigitale & $3.5,2.8,1.3$ & 20 \\
T. mentagrophytes var. mentagrophytes & $3.5,2.8$ & 4 \\
T. mentagrophytes var. quinckeanum & $3.5,1.0$ & 7 \\
T. mentagrophytes var. erinacei & $1.5,0.4$ & 1 \\
T. rubrum & $3.4,2.5,0.6,0.3$ & 10 \\
T. violaceum & $3.5,2.6,1.1,0.4$ & 3 \\
T. ajelloi & $1.9,0.7,0.5$ & 1 \\
T. equinum var. autotrophicum & $3.4,2.8,1.0$ & 1 \\
T. schoenleinii & 1.0 & 1 \\
T. terrestre & $3.5,1.2,0.9,0.7$ & 1 \\
T. tonsurans & $3.4,2.8,0.9$ & 6 \\
Microsporum canis & $3.0,1.2$ & 3 \\
M. persicolor & $2.6,1.3,1.0$ & 1 \\
M. cookei & $2.7,1.2$ & 1 \\
Epidermophyton floccosum & 0.7 & 4 \\
\hline
\end{tabular}


other two T. mentagrophytes varieties examined (var. quinckeanum and var. erinacei) also demonstrated distinct band patterns (bands of 3.5 and $1.0 \mathrm{~kb}$ for the former and bands of 1.5 and $0.4 \mathrm{~kb}$ for the latter) (Fig. 11-m). It was significant that all other dermatophyte species produced characteristic band patterns as well in the AP-PCR with the random primer (Fig. $1 n-x$ and Table 1 ). The negative (no template DNA) control displayed no band at all in the test (Fig. 1y).

\section{Discussion}

The results obtained suggest that although $T$. mentagrophytes varieties are taxonomically closely related, they possess certain unique genetic structures, which are detectable by DNA amplification technology. The observation that $T$. mentagrophytes var. interdigitale isolates formed DNA bands of 3.5, 2.8 and $1.3 \mathrm{~kb}$ and var. mentagrophytes isolates produced bands of 3.5 and $2.8 \mathrm{~kb}$ only in the AP-PCR with the random primer $5^{\prime}$ GAGCCCGACT-3' makes their genetic differentiation possible. In addition, the other two T. mentagrophytes varieties, i.e., var. quinckeanum and var. erinacei, appeared to be distinguishable from $T$. var. interdigitale and var. mentagrophytes, and also from each other, as they showed characteristic bands in the AP-PCR with the random primer. Furthermore, it would be interesting to examine other $T$. mentagrophytes varieties such as T. mentagrophytes var. nodulare, and see if they can also be distinguished in the AP-PCR with this random primer.

Despite its reliance on random priming events, the AP-PCR is remarkably reproducible. Similar to the earlier report [8], AP-PCR with the random primer $5^{\prime}$ GAGCCCGACT-3' is also reasonably robust in that all major bands can be repeatedly obtained from run to run (data not shown). As the AP-PCR involves DNA amplification, it is highly sensitive and rapid compared to conventional methods. Moreover, because of its ability to detect differences at the genetic level, the
AP-PCR is intrinsically precise, and is not subject to the phenotypic variations which are commonly shown by dermatophytes, frequently affecting the interpretation of in-vitro culture results. In fact, of the $T$. mentagrophytes, T. rubrum and T. tonsurans isolates examined, some demonstrated considerable variations in terms of colony colour and morphology, and yet gave the same band patterns as those with typical cultural characteristics (data not shown).

The exact genetic structures and functions of the characteristic bands amplified from Trichophyton dermatophytes with the random primer 5'-GAGCCCGACT-3' are not clear at the moment; however, it is anticipated that the ongoing analysis of the nucleotide base sequences of these bands will shed further light into the molecular basis of and genetic relationship among various Trichophyton species and varieties, and result in further improvement in PCR-based assays for the diagnosis of human dermatophytosis in terms of specificity and direct application to clinical specimens.

\section{References}

1. Weitzman I, Summerbell RC. The dermatophytes. Clin Microbiol Rev 1995; 8: 240-259.

2. Sinski JT, Kelley LM. A survey of dermatophytes from human patients in the United States from 1985-1987. Mycopathologia 1991; 14: 117-126.

3. Rippon JW. Forty four years of dermatophytes in a Chicago clinic (1944-1988). Mycopathologia 1992; 119: 25-28.

4. Rippon JW. Medical mycology: the pathogenic fungi and the pathogenic actinomycetes, 3rd edn. Philadelphia, WB Saunders Company: 1988.

5. Welsh J, McClelland M. Fingerprinting genomes using PCR with arbitrary primers. Nucleic Acids Res 1990; 18: 72137218.

6. Williams JGK, Kubelik AR, Livak KJ, Rafalski JA, Tingey SV. DNA polymorphisms amplified by arbitrary primers are useful as genetic markers. Nucleic Acids Res 1990; 18: 6531-6535.

7. Caetano-Anolles G, Bassam BJ, Gresshoff PM. DNA amplification fingerprinting using very short arbitrary oligonucleotide primers. Biotechnology 1991; 9: 553-557.

8. Liu D, Coloe S, Pedersen J, Baird R. Use of arbitrarily primed polymerase chain reaction to differentiate Trichophyton dermatophytes. FEMS Microbiol Lett 1996; 136: 147-150. 